кuLTura - мeDia- TeoLogia

ISSN 2081-8971

$2017 \mathrm{nr} 30$, s. $122-135$.

\title{
Public relations w kształtowaniu wizerunku polskiego publicznego szkolnictwa na poziomie szkół średnich i gimnazjów
}

\author{
Public relations in shaping the image of polish, public education \\ at the level of primary and secondary schools
}

\begin{abstract}
STRESZCZENIE:
CELEM ARTYKUEU JEST OMÓWIENIE PROBLEMATYKI ZWIĄZANEJ Z KREOWANIEM WIZERUNKU PRZEZ POLSKIE SZKOŁY PUBLICZNE. W SZCZEGÓLNOŚCI, ANALIZIE PODDANE ZOSTAEY TECHNIKI, NARZĘDZIA I KANAEY KOMUNIKACJI PROWADZONE PRZEZ TE JEDNOSTKI. PODSTAWOWE PYTANIE, KTÓRE PRZYŚWIECA PODJĘTYM TU ROZWAŻANIOM, ODNOSI SIĘ DO ZASADNOŚCI SAMEJ KOMUNIKACJI, SPOSOBÓW JEJ REALIZACJI I UŻYTYCH DO REALIZACJI TEGO CELU KANAEÓW KOMUNIKACYJNYCH.

CAŁoŚĆ ROZWAŻAŃ ZOSTAEA OSADZONA W RAMACH TEORETYCZNYCH TZW. KRYTYCZNEJ ANALIZIE DYSKURSU I POPARTA ANALIZĄ PRZYTOCZONYCH PRZYKEADÓW, TJ. KOMUNIKACJI BEZPOŚREDNIEJ W ŚWIECIE RZECZYWISTYM ADRESOWANEJ DO RODZICÓW, IMIENNEJ KOMUNIKACJI POŚREDNIEJ PRZY UŻYCIU LIBRUSA, KOMUNIKACJI POŚREDNIEJ PRZY UŻYCIU STRON INTERNETOWYCH PROWADZONYCH PRZEZ PLACÓWKI ORAZ INFORMACJE MEDIALNE O SZKOLE I JEJ DZIAEANIACH. CELEM BADANIA JEST USTALENIE POZIOMU PROWADZENIA I WYKORZYSTANIA ŚRODKÓW ORAZ NARZĘDZI, ZA POMOCĄ KTÓRYCH SZKOŁY PUBLICZNE NA TERENIE RP BUDUJĄ SWÓJ WIZERUNEK.
\end{abstract}

\section{SŁOWA KLUCZOWE:}

BUDOWANIE WIZERUNKU, KOMUNIKACJA, PUBLICZNE INSTYTUCJE OŚWIATOWE

\begin{abstract}
:
THIS ARTICLE AIMS TO DISCUSS ISSUES RELATED TO CREating THe IMAGE OF THE Polish PUblic SCHOOLS. THE ANALYSIS COVERED TECHNIQUES, TOOLS AND COMMUNICATION CHANNELS. THE BASIC QUESTION THAT GUIDED MEDITATIONS TAKEN HERE, REFERS TO THE VALIDITY OF THE SAME COMMUNICATION, WAYS OF IMPLEMENTATION AND USED FOR THAT PURPOSE COMMUNICATION CHANNELS. THE WHOLE DISCUSSION HAS BEEN SET IN THE FRAMEWORK OF THEORETICAL THE SOCALLED CRITICAL DISCOURSE ANALYSIS AND SUPPORTED BY AN ANALYSIS OF THE EXAMPLES, IT IS DIRECT REAL-WORLD COMMUNICATION ADDRESSED TO PARENTS REGISTERED INDIRECT COMMUNICATION WITH LIBRUS, INDIRECT COMMUNICATION VIA WEBSITES OPERATED BY INSTITUTIONS AND MEDIA INFORMATION ABOUT THE SCHOOL AND ITS ACTIVITIES. THE AIM OF THE STUDY IS TO DETERMINE THE MEASURES AND TOOLS AND THE MEANS BY WHICH PUBLIC SCHOOLS IN POLAND BUILD ITS IMAGE.
\end{abstract}

\section{KEYWORDS:}

PUBLIC RELATIONS, COMMUNICATION, PUBLIC EDUCATIONAL INSTITUTIONS 
$\mathrm{S}$ zkolnictwo w Polsce jest powszechne i bezpłatne, a nauka obowiązkowa dla osób poniżej 18 roku życia ${ }^{1}$, zatem dostęp do placówek oświatowych nie stanowi problemu, jedynie w niewielkiej części szkół przyjęcie ucznia zależy od średniej jego ocen. Oczekiwanym wkładem ze strony ucznia są więc dobre wyniki w nauce. W dobie niżu demograficznego inną sytuację na rynku oświatowym mają szkoły, które dla utrzymania odpowiedniego poziomu nauczania oraz pozyskania odpowiedniej liczby uczniów, a co za tym idzie utrzymania zatrudnienia nauczycieli i utrzymania odpowiedniego statusu instytucji, muszą zabiegać o klienta - ucznia. Dotyczy to zarówno szkół publicznych, jak i niepublicznych. Podejmując to wyzwanie szkoły, mimo iż są instytucjami niekomercyjnymi, muszą mierzyć się z zadaniami w obszarze public relations. „Public relations jest funkcją zarządzania o ciągłym i planowym charakterze, dzięki której organizacja pozyskuje i podtrzymuje zrozumienie, sympatię i poparcie tych, którymi jest zainteresowana obecnie lub może być zainteresowana w przyszłości - przez badanie ich opinii o organizacji, w celu maksymalnego dostosowania do swoich celów i swojej działalności, aby osiągnąć poprzez planowe, szerokie rozpowszechnianie informacji lepszą współpracę ze społeczeństwem oraz skuteczniej realizować swoje interesy"22.

Działania public relations w odniesieniu do placówek oświatowych pełnią funkcję zarządzania, stanowią element promocji i narzędzie marketingu. Podejmowanie działań w tym obszarze jest niezbędne do funkcjonowania szkół i pozyskania uczniów. Czynniki motywujące do budowania pozytywnego wizerunku:

- $\quad$ brak obligatoryjnej rejonizacji uczniów i możliwość wyboru dowolnej placówki oświatowej przez ucznia,

- podniesienie prestiżu szkoły,

- pozyskanie większej ilości kandydatów/uczniów,

- pozyskanie kandydatów z większym potencjałem,

- rozwój instytucji.

Powyższe czynniki skłaniają do podejmowania kroków tworzących zewnętrzne public relations, które „ma charakter wtórny w stosunku do działalności podstawowej”3. W istocie, należy więc uregulować i uporządkować wewnętrzny system działania instytucji, placówki oświatowej tak, aby wewnętrzne public relations funkcjonowało nienagannie, a w drugiej kolejności zadbać o działania adresowane do odbiorców zewnętrznych. „Dopiero realizowane na tej bazie zewnętrzne public relations, może przynieść spodziewane rezultaty-ugruntuje oraz upowszechni pozytywny wizerunek jednostki w szerszym otoczeniu"4. W przypadku instytucji działających

\footnotetext{
${ }^{1}$ Ustawa z dn.7 września 1991r. o systemie oświaty z późn. zmianami, (publikacja 30-11-2015), Dz.U. z 2015

r. poz 2156 oraz z 2016r.poz 35 i 64, isap.sejm.gov.pl/Download?id=WDU20042562572\&type=3, (dostęp

11.12.2017r.)

${ }^{2}$ S. Cutlip, A Center, Effective Public relations, Englewood Cliffs 1978, s. 15.

${ }^{3}$ A. Pabian, Promocja, nowoczesne środki i formy, Diffin, Warszawa 2008, s. 144.

${ }^{4}$ Tamże, s. 144.
} 


\section{PUBLIC RELATIONS W INSTYTUCJACH NON-PROFIT}

w obszarze edukacji działania w obydwu obszarach częstokroć przenikają się i są nierozłączne.

Wizerunek publiczny to efekt zarządzania tożsamością organizacji, zatem działania PR obejmują trzy obszary:

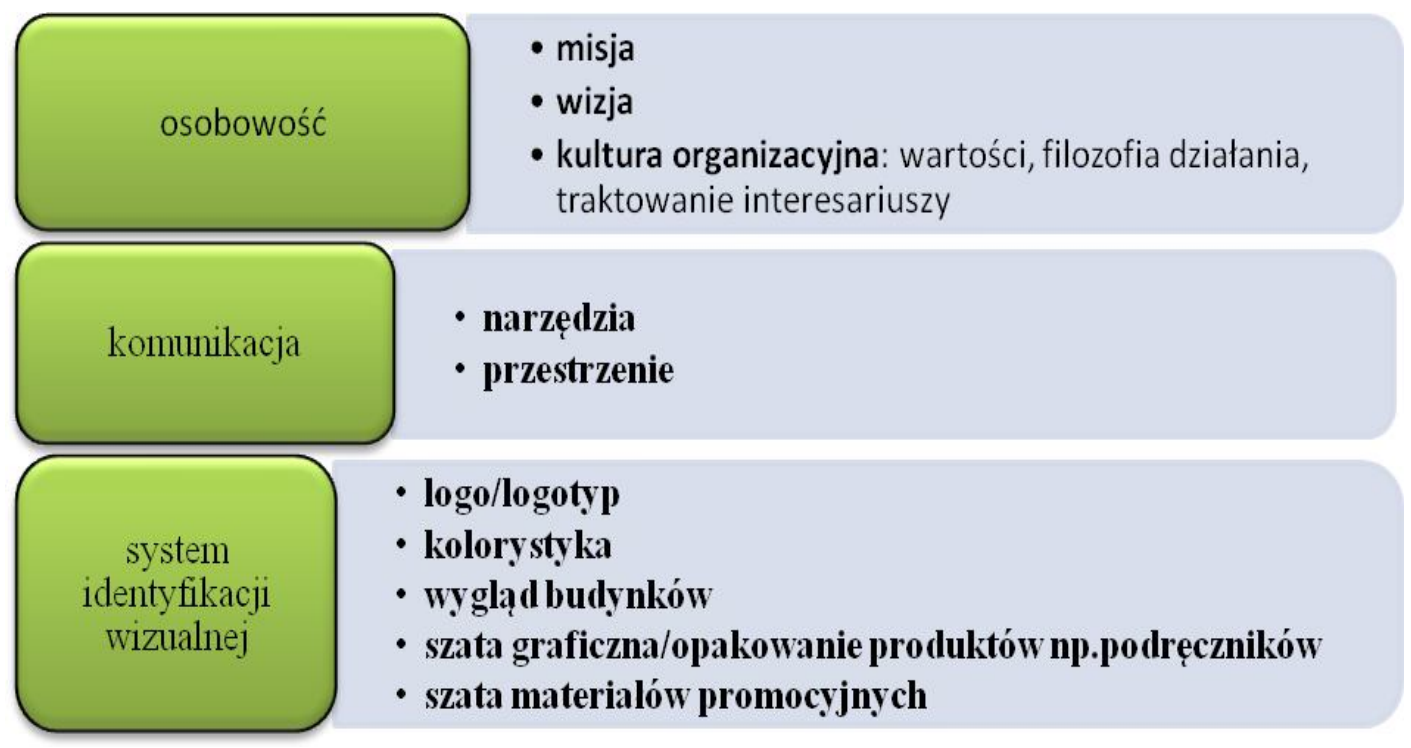

Ryc. Opracowanie własne na podstawie Public Relations wsystemie zintegrowanej komunikacji marketingowej A. Szymańska, s. $89-90^{5}$.

\section{Działania szkół w ramach PR:}

- tworzenie systemu identyfikacji wizualnej,

- prowadzenie stron internetowych placówek,

- komunikacja za pomocą dzienników wirtualnych np. Librus Synergia,

- tworzenie prasy szkolnej,

- prowadzenie fanpage'a na $\mathrm{FB}$,

- pozyskiwanie rodziców do czynnego udziału w życiu szkoły,

- dni otwarte, dni kariery.

- informacje prasowe o działaniach.

Pierwsze z analizowanych działan, to prowadzona strona internetowa Zespołu Szkół Ponadgimnazjalnych im T. Kościuszki w Sobolewie ${ }^{6}$.

\footnotetext{
${ }^{5}$ A. Szymańska, Public relations w systemie zintegrowanej komunikacji marketingowej, Oficyna Wydawnicza Unimex, Wrocław 2004, s. 89-90.

${ }^{6}$ Strona internetowa ZSP im. T. Kościuszki w Sobolewie, (brak daty publ.), http://www.losobolew.pl/, dostęp 18.11.2017 r.).
} 


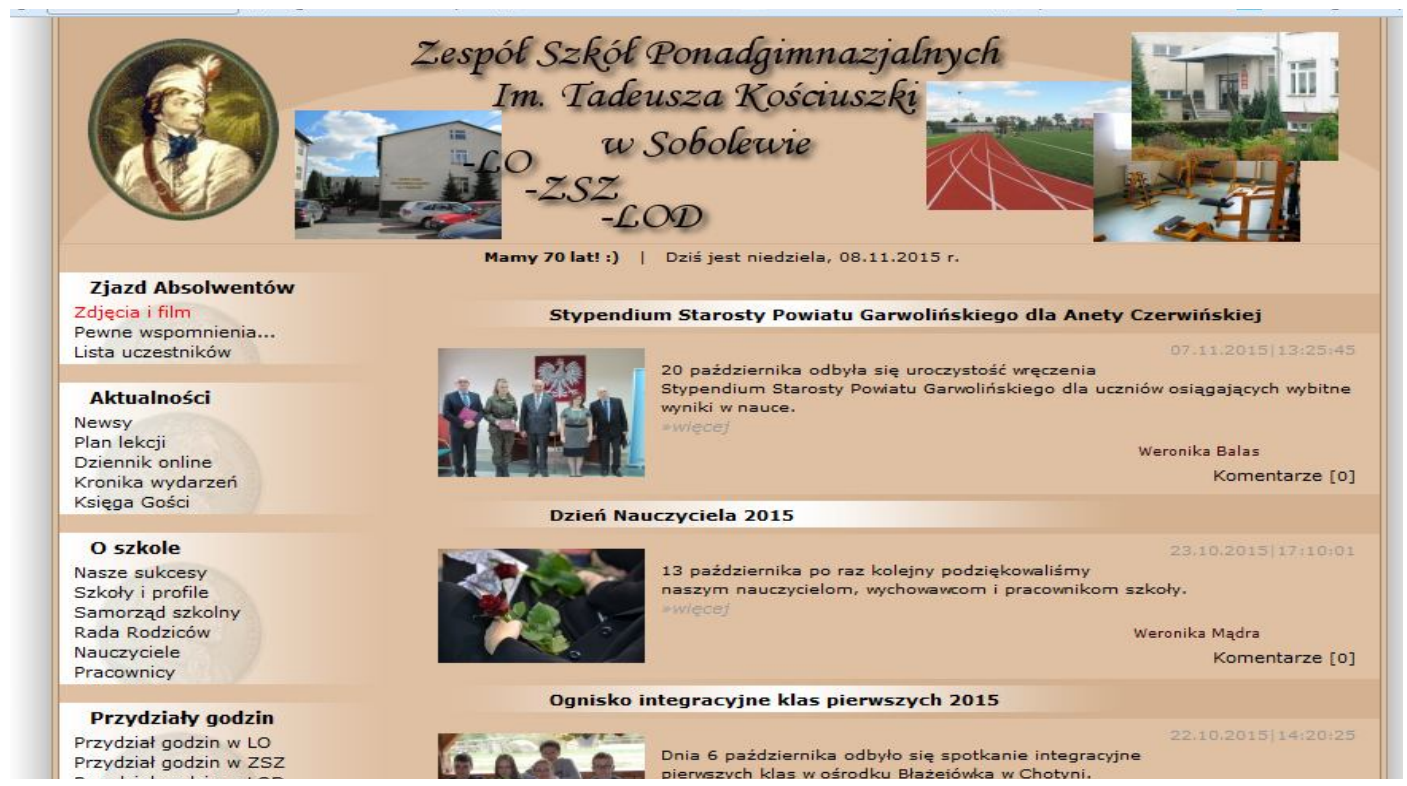

Podstawową funkcją tego przedsięwzięcia jest aspekt informacyjny - odbiorca znajduje istotne informacje na temat działalności i funkcjonowania szkoły. Grupy tematyczne zawierają $\mathrm{n} / \mathrm{w}$ informacje to:

1. aktualności - newsy, plan lekcji, dziennik online, kronikę wydarzeń, księgę gości.

2. o szkole - nasze sukcesy, szkoły i profile, samorząd szkolny, rada rodziców, nauczyciele, pracownicy.

3. dokumenty - statut, wso (wewnątrzszkolny system oceniania) i regulaminy, programy i podręczniki, program wychowawczy.

4. matura 2016: terminarz ,procedury, pomoce na maturze, środowiska na egzamin z informatyki, dostosowania egzamin, przydatne materiały, tematy na maturę ustną.

5. przydziały godzin: wykaz: LO, LOD, ZSZ.

6. historia: historia szkoły, wspomnienia, patron, absolwenci, tabla, dyrektorzy, nauczyciele, samorząd szkolny, rada rodziców, administratorzy.

7. galerie, video: fotokronika, obiekty szkolne, studniówki, zdjęcia klasowe, obozy szkolne, zjazdy absolwentów.

8. „Nikomu Ani Słowa”.

9. dział sportowy.

10. Zespół NIEprzeciętni.

11. dopalacze.

12. przetargi.

13. kontakt, napisz do nas.

14. statystyki odwiedzin.

15. patroni medialni. 
Adresatami są wszyscy partnerzy placówki: nauczyciele, uczniowie, rodzice uczniów; co ważne - odbiorcami mogą być również przyszli kandydaci na uczniów i ich rodzice. Przekaz wypływający z obszaru informacyjnego świadczy o dużej dbałości placówki o jej właściwe funkcjonowanie, o dobrym przepływie informacji i bogactwie działalności programowej oraz pozaprogramowej, wiążącej się z edukacją, wychowaniem, kulturą i profilaktyką. Tym samym, odbiorca zewnętrzny kształtuje przekonanie, że placówka dokłada starań, aby uczniowie otrzymali wszechstronną wiedzę, wykraczającą poza program nauczania, rodzic natomiast może poszerzyć swoje wiadomości o istotne informacje potrzebne do właściwego wychowania, ukształtowania i ochrony dziecka. Potwierdzeniem tego fragmentu przekazu są zastosowane narzędzia wizualne, a więc stonowana, niekrzykliwa kolorystyka, prosta, czytelna czcionka, grupowanie informacji, graficzne rozdzielenie zakładek i wyboldowanie ich nazw. Pod kątem merytorycznym zauważalny jest logiczny porządek informacji, brak nadmiaru przekazywanych treści, umieszczenie ograniczonej liczby zdjęć ułatwiające poprawę percepcji. Zastosowano językowy styl urzędowy we wszystkich publikacjach. Dzięki powyższym działaniom metakomunikat wypływający z postrzegania w/w strony internetowej, utożsamiany przez odbiorcę z cechami placówki informuje o jej profesjonalizmie, rzetelności, powadze, poszanowaniu dla historii i tradycji, uporządkowaniu, logiczności. Są to zatem cechy pożądane dla szkoły dbającej o wysoki poziom nauczania i wychowania oraz skuteczność podejmowanych działań profilaktycznych. Narzędzie to służy do przekazania informacji o misji, wizji i kulturze organizacyjnej placówki, spełnia również rolę komunikatora i buduje system identyfikacji wizualnej przez umieszczenia obrazu sztandaru i nazwy.

Kolejne narzędzie PR służące komunikacji, ale również budujące identyfikację wizualną przez zamieszczenie wizerunku patrona inazwy szkoły jest Dziennik elektroniczny - Librus Synergia, zastosowany przez Zespół Szkół w Sobolewie ${ }^{7}$.



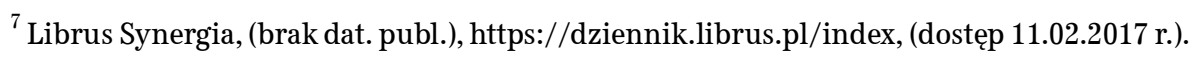


Narzędzie to służy do komunikacji pomiędzy nauczycielami i dyrekcją szkoły a uczniami oraz rodzicami. Zarówno rodzice uczniów, jak i uczniowie posiadają niezależne możliwości logowania się do jednego konta i prowadzenia suwerennych działań, jak też pozyskiwania odpowiednich informacji i prowadzenia korespondencji. Platforma komunikacyjna Librus Synergia zawiera następujące działy tematyczne: oceny, frekwencja, wiadomości, terminarz, zadania domowe, ogłoszenia, organizacja zajęć, plan lekcji, lekcje (realizacja materiału), pliki szkoły (regulaminy, programy, system oceniania itp.), lektury (wykaz), wyniki egzaminów, konkursów, podręczniki (wykaz). Istnieje również możliwość aktywowania dodatkowych platform: Antyplagiat, e-nauczanie, MegaMatma, Kontrola ocen dziecka i frekwencji, Indywidualni (platforma pedagogiczna dla rodziców).






Jak widać, platforma pod kątem komunikacyjnym zawiera wszystkie potrzebne elementy.

Dla realizacji indywidualnych potrzeb istnieje możliwość skorzystania z e-learningu. Stonowana kolorystyka tła i różnobarwne znaczniki rozróżniające istotne informacje wpływają na poprawę percepcję odbiorcy. Czytelność przekazu ibrak szumu informacyjnego spowodowanego nadmiarem dają informację odbiorcy - rodzicowi, uczniowi, że misją placówki jest dbałość o wysoki poziom kontaktu z petentem i zapewnienie uczniowi możliwości realizacji powierzonych zadań i stawianych przed nim oczekiwań. Zysk jest oczywisty i czytelny, dotyczy bezpośrednio budowania dobrego wizerunku poprzez:

- ułatwianie komunikacji pomiędzy rodzicami, uczniami i nauczycielami,

- budowanie dobrych relacji, zaufania i współpracy,

- promowanie szkoły przez informowanie rodziców o działaniach, akcjach, projektach,

- pozyskiwanie nowych zasobów (profesje rodziców, działalności, umiejętności),

- informowanie o osiągnięciach szkoły i uczniów,

- uzyskiwanie wsparcia dla szkoły przez czynne ze strony wsparcie rodziców, uczniów, sympatyków w konkursach, w których uczestniczy placówka lub jej przedstawiciele.

Narzędzia wykorzystane w tym działaniu opierają się o kompleksowość, zastosowanie stylu urzędowego, czytelność komunikatów. Skutkuje to czytelnością całej platformy. Metakomunikat kształtujący opinie odbiorcy obejmuje informacje o tym, że instytucja posługuje się profesjonalnym narzędziem w celu wysokiej efektywności i dobrej komunikacji, a to stanowi o jej profesjonalizmie. Celem szkoły, oprócz edukacji i wychowania, jest dbałość o rzetelne wykonywanie ustawowych zadań. Placówka jest więc godna zaufania i warto jej powierzyć edukację swojego dziecka.

Kolejny niezwykle istotny sposób kreowania wizerunku placówki i jednocześnie poszarzania oferty edukacyjnej dla uczniów, to prowadzenie wewnątrzszkolnej prasy. Przykładem jest tu gazetka pt. „Nikomu Ani Słowa”, wydawana przez uczniów Liceum Ogólnokształcącego w Zespole Szkół Ponadgimnazjalnych im. Tadeusza Kościuszki w Sobolewie ${ }^{8}$.

Profesjonalna redakcja i szeroka tematyka obejmują media, kulturę, sferę polityczno-społeczną, sport i profilaktykę. Redakcją i pisaniem artykułów zajmują się sami uczniowie pod opieką dwojga nauczycieli: polonistki i informatyka. Szata graficzna jest stonowana, przejrzysta, daje informacje o profesjonalizmie i budzi zaufanie czytelnika.

Funkcje podstawowe, to tworzenie profesjonalnej prasy i edukacja uczniów w tym zakresie. Zarówno uczniowie piszący do tej gazety, jak i czytelnicy poszerzają swoją wiedzę w zakresie kulturoznawstwa i socjologii. Możliwość współtworzenia

\footnotetext{
${ }^{8}$ Nikomu ani słowa, (brak daty publ.), http://redakcja.mam.media.pl/paper/preview/nikomu-ani-s \%C5\%82owa/15/3/17/, (dostęp 11.12.2017 r.).
} 
projektu wiążącego się z mediami rozwija kreatywność, powoduje współudział w zajęciach fakultatywnych i jest zarazem twórczą profilaktyką. Funkcja pośrednia wynikające z powyższego działania, to poszerzenie oferty edukacyjnej prowadzonej na wysokim poziomie. Pośrednia, ale niezwykle ważna informacja wypływająca ze świadomości tworzenia przez szkołę własnej prasy, to szerokie działania ponadprogramowe placówki, duże zaangażowanie pedagogów i młodzieży, dobre relacje między kadrą a uczniami. Ogólna opinia powstająca po zapoznaniu się z działaniami PR prowadzonymi w tej szkole jest pozytywna, daje przeświadczenie, że jest to placówka dbająca o ucznia, edukację, dobrą atmosferę i właściwe relacje oparte o współpracę i wzajemną troskę oraz wsparcie. Najistotniejszym przesłaniem jest informacja o misji i wartościach kultywowanych w w/w placówce, które w centrum stawiają dobro ucznia i wysoki poziom edukacji.

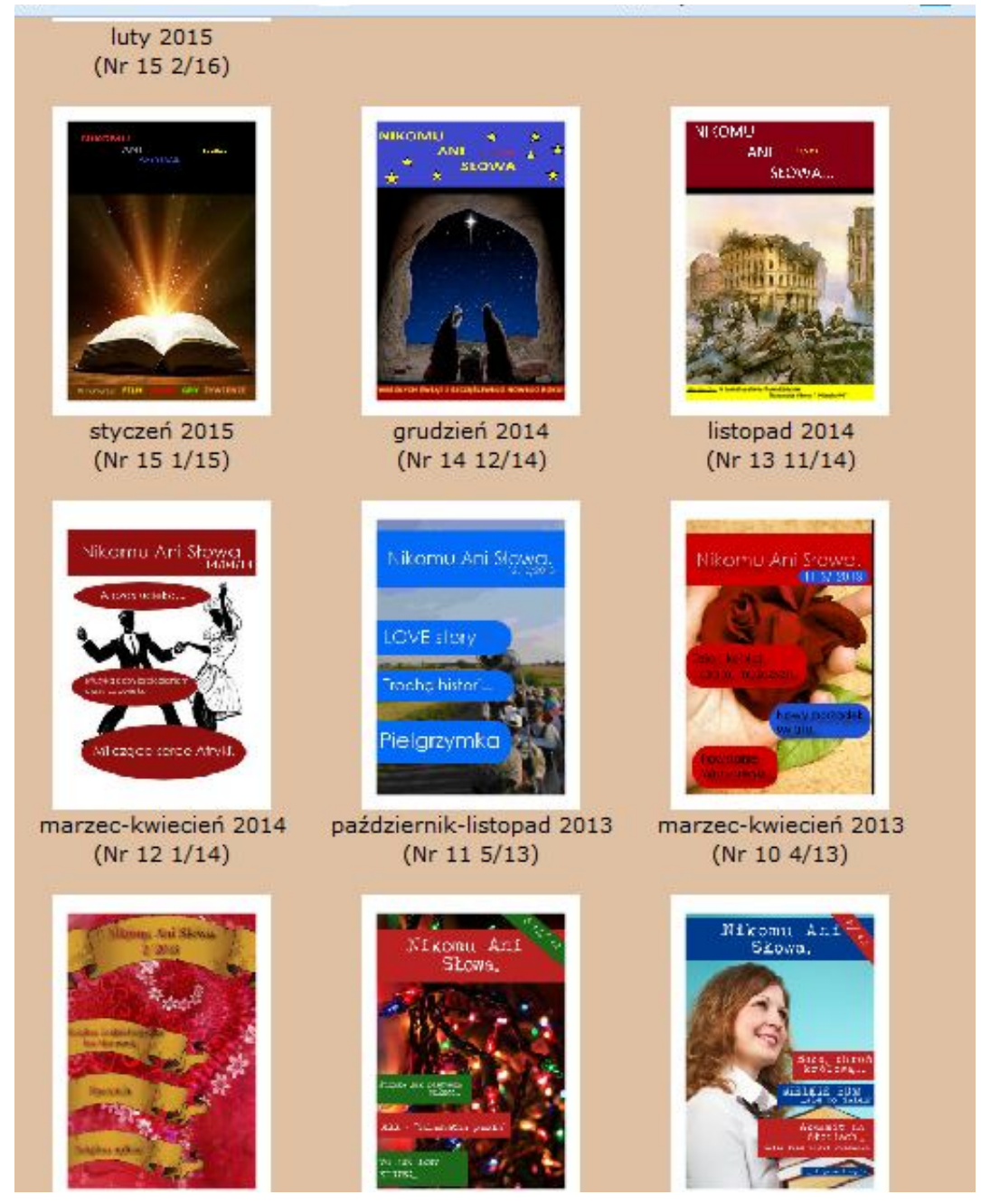



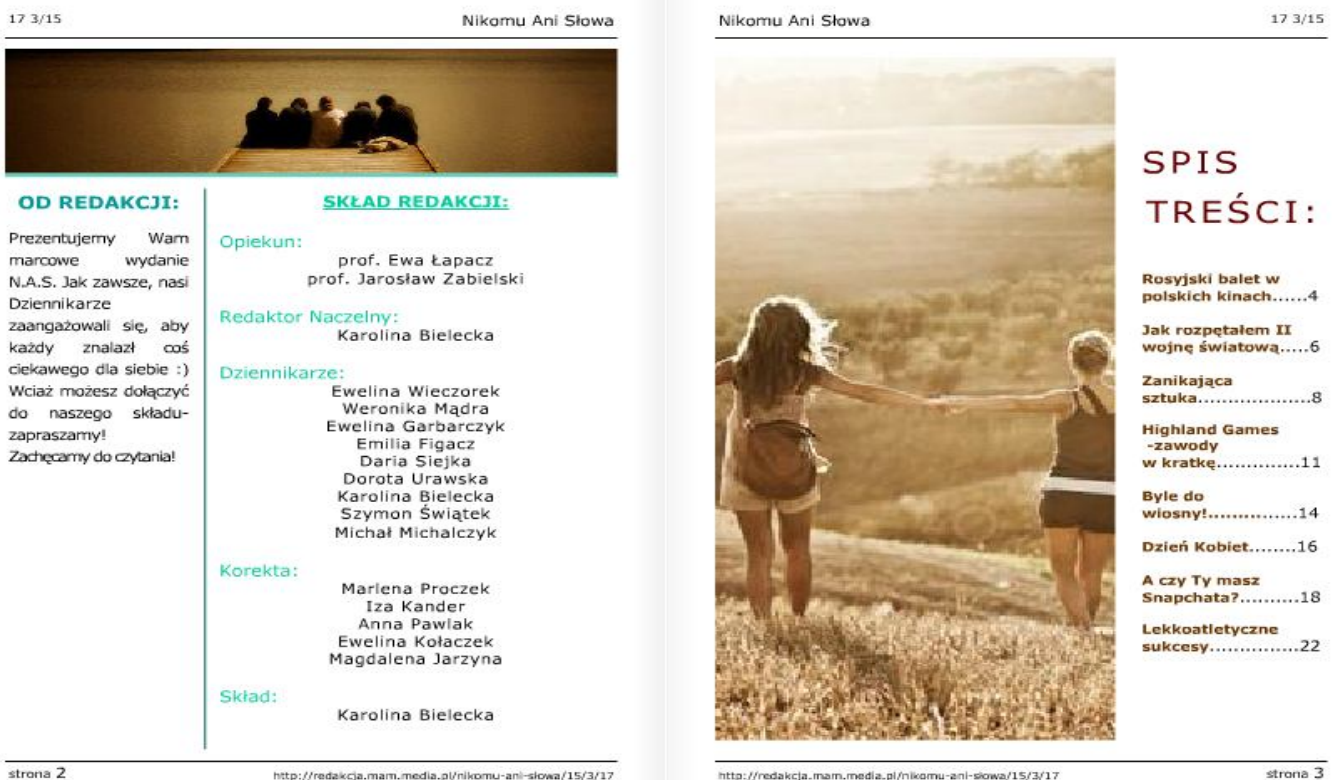

Odmiennym sposobem konstrukcji pozytywnego obrazu instytucji jest prowadzenie fanpage’a szkoły na Facebooku. Ma on na celu poprawę komunikacji pomiędzy szkołą a uczniami oraz zachęcenie uczniów do współtworzenia placówki i czynnego uczestnictwa w jej życiu. Dobrym przykładem jest Publiczne Gimnazjum im. Jana Pawła II w Żelechowie ${ }^{9}$.

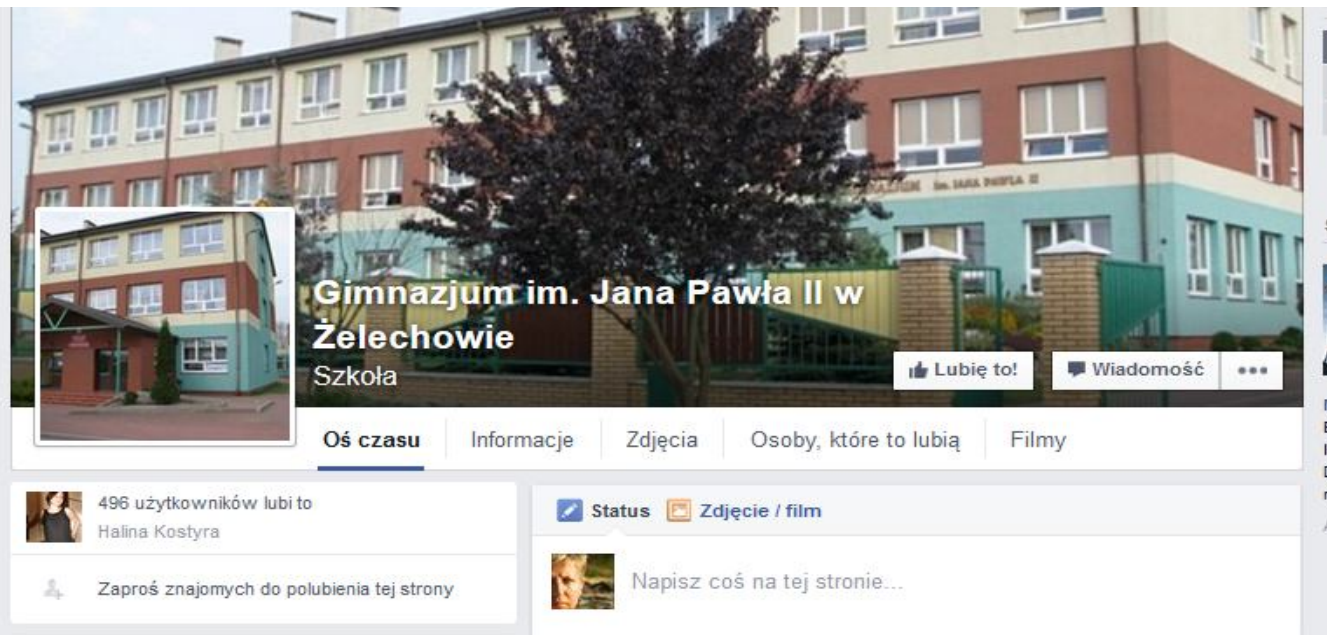

\footnotetext{
${ }^{9}$ PG w Żelechowie - fanpage na FB, (brak daty publ.), https://www.facebook.com/zsogrodowa/? ref=ts\&fref=ts, (dostęp 18.12.2017 r.).
} 
Funkcje podstawowe stawiane przed tym działaniem, to bezpośredni kontakt z uczniami w każdym czasie. Uczniowie w większości pozostają bowiem online przez całą dobę, a przynajmniej przez jej większą częśc. Najistotniejsze jest przekazywanie informacji o działaniach i akcjach prowadzonych w szkole, proponowanych i funkcjonujących zajęciach pozalekcyjnych, propagowanie wydarzeń kulturalnych i relacji z wydarzeń wiążących się z funkcjonowaniem szkoły. To, co istotne, we współczesnym społeczeństwo informacyjnym, to odchodzenie od treści, a posługiwanie się obrazem. Ten sposób przekazu jest niezwykle istotny i jest stosowany przy tworzeniu galerii na Facebooku.

Funkcja pośrednia, znamienna dla tego sposobu komunikacji, to budowanie dobrych, bliskich relacji z uczniami. Styl językowy jest więc zbliżony do stylu potocznego, oczywiście istotnym jest tu także zachowanie poszanowania ogólnie przyjętych norm społecznych. Tworzony jest w ten sposób dobry wizerunek szkoły pozostającej w bliskich relacjach z uczniami; szkoły nastawionej również na kształtowanie ucznia w zakresie pozytywnej postawy społecznej i emocjonalnej. Dzięki temu, łatwiej jest placówce edukacyjnej pozyskać uczniów oczekujących od placówki edukacyjnej nie tylko nauki, ale też dobrych relacji, więzi i wsparcia społecznego; szkoły nadążającej za zmianami społecznymi, technologicznymi, otwartej na nowości i zmniejszenie dystansu na linii pedagog - uczeń. Wydaje się też, że rodzice uczniów trudniejszych społecznie, zamkniętych na otoczenie, chętniej zainteresują się w/w placówką z uwagi na konieczność kształtowania w dziecku otwartości nauki właściwych relacji międzyludzkich. Zatem, na pierwszy plan wysuwają się ponownie: misja i wizja szkoły, najważniejszy jest tu uczeń i jego osobowość, istotne są też wyniki w nauce i szeroko pojęta edukacja, również ta pozalekcyjna. Placówka stawia na kształtowanie młodego człowieka i jego dobre relacje z innymi ludźmi w wielu działaniach pozalekcyjnych, dodatkowych. Oferta edukacyjna jest zatem równie istotna i bogata, wiąże się funkcjonowaniem chóru szkolnego, zajęciami plastycznymi, artystycznymi, wspólnym spędzaniem czasu podczas dyskotek i innych zajęć służących relaksowi i budowaniu wspólnych więzi. I choć podstawowym adresatem tego działania są uczniowie, to rodzice, jako adresat poboczny, otrzymują pozytywną informację o szkole.

Bardzo wysoko cenionym narzędziem w budowaniu wizerunku placówek oświatowych są informacje prasowe o działaniach szkoły i prowadzonej współpracy z rodzicami. „Naczelną zasadą public relations jest (...) stwierdzenie, że media transportują komunikat między organizacja, a grupami odniesienia. (...) Public relations zatem to specyficzny rodzaj komunikacji, bazujący oczywiście na ogólnym mechanizmie komunikacji, lecz specyficznie ukierunkowany"10. Ukierunkowanie polega na dotarciu do grup społecznych zainteresowaniem edukacją w kontekście wychowania i edukacji swoich dzieci czy wnucząt. Reprezentatywną dla dobrych praktyk komunikacyjnych jest publikacja o uroczystości przygotowanej przez nauczycieli i uczniów Zespołu Szkół w Sobolewie - XII Biesiadzie Rodzinnej w Sobolewie ${ }^{11}$.

\footnotetext{
${ }^{10}$ M. Fleischer, Corporate identity i public relations, Dolnośląska Szkoła Wyższa Edukacji Towarzystwa Wiedzy Powszechnej, Wrocław 2003, s. 177.

${ }^{11}$ XII Biesiada Rodzinna w Sobolewie, (brak daty publ.), http://www.egarwolin.pl/index.php/rozrywka/5311-
} 
Informacja prasowa przygotowana przez pracowników szkoły wraz z dokumentacją fotograficzną została przekazana do informacyjnego portalu regionalnego eGarwolin ${ }^{12}$ obejmującego zasięgiem działania powiat garwoliński. Informacja zawiera relację ze spotkania integracyjnego dedykowanego uczniom i rodzicom uczniów w/w placówki przygotowanego z okazji dnia dziecka, bardzo bogatą ofertę służącą rekreacji, zdrowemu stylowi życia, propagującą dobre relacje międzyludzkie, współdziałanie w grupie społecznej i wsparcie placówki edukacyjnej tworzy istotną podbudowę do pozyskiwania kolejnych uczniów i nawiązywania współpracy z rodzicami, dzięki czemu działania na rzecz uczniów i placówki mogą być bogatsze i ciekawsze, asami uczniowie mogą korzystać z szerszej oferty. Pośrednio informacja przekazywana do ogółu społeczeństwa tworzy obraz szkoły dbającej o edukację i modelowanie społeczne młodych ludzi.

Tożsamą kreacją wizerunku szkoły jest publikacja dotycząca dni otwartych prowadzonych w Liceum Ekonomicznym w Garwolinie pt. Gimnazjalisto, dowiedz się, dlaczego warto wybrać, ,ekonomik" ${ }^{\sharp 3}$.

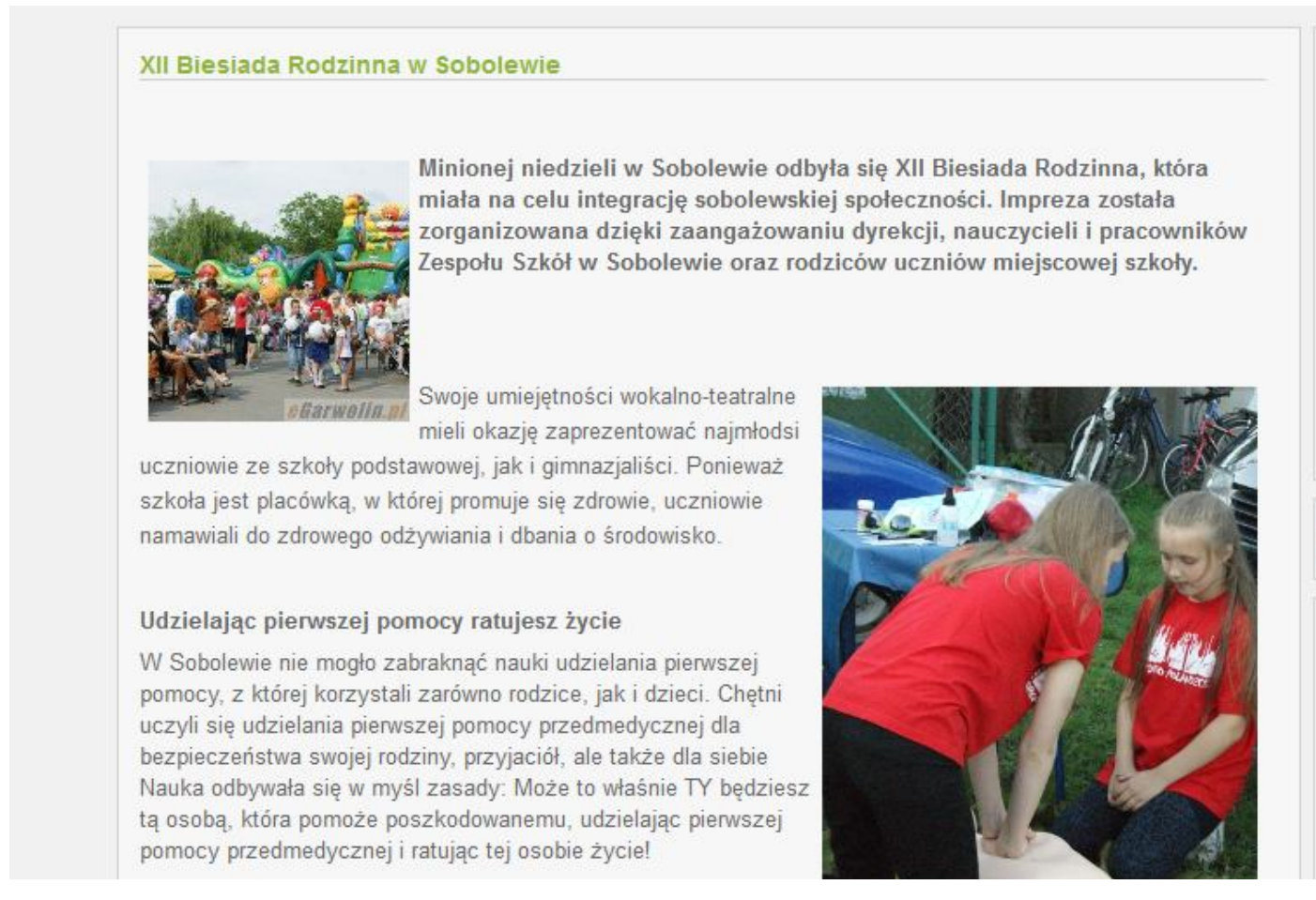

xii-biesiada-rodzinna-w-sobolewie, (dostęp 11.12.2017 r.).

${ }^{12}$ eGarwolin - Regionalny Portal Internetowy, egarwolin.pl, (dostęp 18.12.2017 r.).

${ }^{13}$ Gimnazjalisto dowiedz się dlaczego warto wybrać ekonomik, (publikacja 01.04.2012 r.),

http://www.grajdol.pl/garwolin_4746_gimnazjalisto_dowiedz_sie_dlaczego_warto_wybrac_ekonomik,9, (dostęp 18.12.2017 r.). 
Powyższa informacja skonstruowana w stylu publicystycznym przybliża atuty szkoły, jej otwartość na uczniów oraz potrzebę edukowania na najwyższym poziomie. Nie pominięto również informacji o bogatej ofercie edukacji ponadprogramowej i pozalekcyjnej wiążącej się często z rekreacją i budowaniem dobrych relacji rówieśniczych.

Funkcje publikacji prasowych promujących szkoły, profesjonalizm działań i nastawienie na indywidualne traktowanie ucznia oraz dobre funkcjonowanie społeczne spełniają kilka zadań, są to przede wszystkim:

- promocja szkoły w lokalnym społeczeństwie,

- pozyskiwanie uczniów,

- informowanie niezaangażowanych rodziców o ofercie placówki i podejmowanych działaniach na rzecz uczniów i społeczności,

- pozyskiwanie rodziców do współpracy,

- budowanie dobrych relacji i zaufania między stronami.

Aspekt socjologiczny w budowaniu wizerunku firmy, placówki oświatowej jest niezwykle ważny, gdyż „badania sieci powiązań dowodzą, że procesy wymiany informacji nie zachodzą w abstrakcyjnych sytuacjach rynkowych, lecz w ramach więzi społecznych" ${ }^{\text {. }}$. Upowszechnianie informacji o pozytywnym wizerunku szkoły skutkuje dwojakim zyskiem, stanowi formę reklamy i bezpośrednio daje efekt marketingu tradycyjnego i szeptanego; informuje również o kultywowaniu przez placówkę wartości postrzeganych jako istotne przez potencjalnych klientów, zwiększa więc prawdopodobieństwo sprzedaży usług. Biorąc pod uwagę fakt, że strategiczne decyzje podejmowane są przez nabywcę $\mathrm{w}$ znacznym stopniu na poziomie paralelizmu wartości i empatii - jest to działanie skuteczne. Wszystkie te założenia mają budować dobry wizerunek szkoły, mają pełnić funkcję informacyjną i zarazem stanowić formę reklamy, a przez to budować rynek zbytu na usługi edukacyjne przez pozyskiwanie kolejnych uczniów.

Funkcja informacyjna może mieć formę potencjalną lub użyteczną. Powyższe kroki budujące wizerunek szkół spełniają funkcje potencjalne i użyteczne, gdyż powiększają zasób wiedzy odbiorcy. Równocześnie, funkcja sterująca wywołuje zamierzony efekt, reakcję u odbiorcy polegającą na kształtowaniu pozytywnego obrazu. Szkoły starają się wpłynąć na tworzenie swojego wizerunku w lokalnej społeczności tak, aby za pomoca funkcji modelowania uwypuklić najistotniejsze informacje i stworzyć obraz instytucji preferującej wartości, na które występuje zapotrzebowanie społeczne. Ponieważ niemożliwe jest równoczesne rozpoznanie wszystkich aspektów funkcjonowania informacji, podczas odbioru dokonuje się uproszczenia, na skutek czego odbiorca formułuje swój obraz, model szkoły, który może być następnie wykorzystany w procesie zarządzania palcówką i pozyskiwania klientów. Świadomość tego procesu pozwala na prowadze-

\footnotetext{
${ }^{14}$ S. Wiesender, T.Cerny, Skuteczne zarządzanie reputacja I spójny image, Best Press Wydawnictwo, Warszawa 2008, s. 40.
} 


\section{PUBLIC RELATIONS W INSTYTUCJACH NON-PROFIT}

nie zrównoważonej konkurencji pomiędzy placówkami oświatowymi sektora publicznego i prywatnego.

Coraz częściej, z coraz większą oczywistością, instytucje zajmujące się edukacją uzmysławiają sobie konieczność budowania swojego kierunku, rozwijania go i kształtowania w odniesieniu do zmian zachodzących na rynku edukacyjnym. „Klienci kupują markę, image, świat przeżyć oferowany przez dana organizację (...)" ${ }^{15}$. Zjawisko to nie tylko generuje potrzebę, zmusza resort oświaty do podejmowania intensywnych działań w tym zakresie, gdyż wynikiem zaniechań lub błędów może być kres funkcjonowania poszczególnych placówek, a co za tym idzie problemy dla zatrudnionych tam osób. Dbanie o dobre imię instytucji to pośrednio dbanie o dobrą przyszłość zatrudnionych w niej osób.

\section{BIBLIOGRAFIA}

Budzyński W., Public Relations. Strategia i nowe techniki kreowania wizerun$\mathrm{ku}$, Poltext, Warszawa 2008.

Cutlip S., Center A., Effective Public relations, Englewood Cliffs 1978.

Fleischer M., Corporate identity i public relations, Dolnośląska Szkoła Wyższa Edukacji Towarzystwa Wiedzy Powszechnej, Wrocław 2003.

Pabian A. , Promocja, nowoczesne środki i formy, Diffin, Warszawa 2008.

Szymańska A, Public relations $w$ systemie zintegrowanej komunikacji marketingowej, Oficyna Wydawnicza Unimex, Wrocław 2004.

S. Wiesender, T. Cerny, Skuteczne zarządzanie reputacja I spójny image, Best Press Wydawnictwo, Warszawa 2008.

\section{ŹRÓDŁA INTERNETOWE}

XII Biesiada Rodzinna w Sobolewie, (data publ. 01.04.2012 r.), http://www.egarwolin.pl/index.php/rozrywka/5311-xii-biesiada-rodzinna-w-sobolewie.

eGarwolin - Regionalny Portal Internetowy, egarwolin.pl.

Gimnazjalisto dowiedz się dlaczego warto wybrać ekonomik, (publikacja 01.04.2012 r.), http://www.grajdol.pl/garwolin_4746_gimnazjalisto_dowiedz_sie_dlaczego_warto_wybrac_ekonomik,9.

Librus Synergia, (brak dat.publ.), https://dziennik.librus.pl/index.

Nikomu ani słowa, (brak daty publ.),

http://redakcja.mam.media.pl/paper/preview/nikomu-ani-s\%C5\%82owa/15/3/17/.

PG w Żelechowie-fanpage na FB, (brak daty publ.), https://www.facebook.com/zsogrodowa/?ref=ts\&fref=ts.

\footnotetext{
${ }^{15}$ M. Fleischer, art. cyt. s. 7.
} 
Ustawa z dn.7 września 1991r. o systemie oświaty z późn. zmianami, (publikacja 30.11.2015), Dz.U. z 2015r.poz2156 oraz z 2016r.poz 35 i 64) (isap.sejm.gov.pl/Download?id=WDU20042562572\&type=3.

ZSP im. T. Kościuszki w Sobolewie - strona internetowa, (brak daty publ.), http://www.losobolew.pl/.

\section{O AUTORCE:}

mgr Danuta Kalinowska - absolwentka Filologii Polskiej na UW, doktorantka z wolnej stopy na Uniwersytecie Warmińsko-Mazurskim w Olsztynie pod opieką naukową dr hab. Arkadiusza Dudziaka. Zawodowo zajmuje się profilaktyką w Komendzie Powiatowej Policji w Garwolinie i dydaktyką w Pedagogium Wyższej Szkole Nauk Społecznych w Warszawie. KONTAKT:dankakalinowska@o2.pl 